\title{
"Syndrome of Contractures" According to Prof. Hans Mau; Problems of Shanks, Knees, Hips, Pelvis and Spine; Children, Adolescents, Adults, Diagnosis, Treatment
}

\author{
Karski Tomasz ${ }^{1}$, Karski Jacek², Domagała Marian² \\ ${ }^{1}$ Vincent Pol University, Lublin, Poland \\ ${ }^{2}$ Medical University, Lublin, Poland \\ ${ }^{3}$ Medical Centre, Laszczów, Poland \\ Email:tmkarski@gmail.com, jkarski@vp.pl,mariandomagala1213@yahoo.pl
}

How to cite this paper: Tomasz, K., Jacek, K. and Marian, D. (2019) "Syndrome of Contractures" According to Prof. Hans Mau; Problems of Shanks, Knees, Hips, Pelvis and Spine; Children, Adolescents, Adults, Diagnosis, Treatment. Surgical Science, 10, 24-38.

https://doi.org/10.4236/ss.2019.101004

Received: December 17, 2018

Accepted: January 21, 2019

Published: January 24, 2019

Copyright $\odot 2019$ by author(s) and Scientific Research Publishing Inc. This work is licensed under the Creative Commons Attribution International License (CC BY 4.0).

http://creativecommons.org/licenses/by/4.0/

\begin{abstract}
The problems of movement apparatus in children, youth and even adolescents aren't connected with "a weakness of muscles" but with a shortening of muscles, tendons, and capsules which in orthopaedic literature is called "contracture" [1] [2] [3] [4]. The older way of thinking about the problem was based on the conviction that "weak muscles" cause and make problems; we, however, present on many examples that "restriction of movements" doing by shortening of soft tissues makes contracture and incorrect position of joints, body parts, the serious and frequent clinical problems.
\end{abstract}

\section{Keywords}

Contracture, Incorrect Position of Body, Influence on Shanks, Hips, Pelvis, Neck, Spine, Physiotherapy

\section{Causes of the "Syndrome of Contractures" (SofC)}

The "syndrome of contractures" (Figures 1-3) has been described with all details by Prof. Hans Mau-as Siebener [Kontrakturen] Syndrom" (syndrome of seven contractures). In 2006 in Lublin we added to "the Syndrome of Contracture" the eighth deformity-bigger than normal "varus of shanks" (Figures 13-15). Now, we describe this syndrome as the "Syndrome of Contractures and Deformities" (SofCD). In literature we find that this syndrome has been described also by: Hensinger, Howorth, Green \& Griffin, Dega, Vizkelety, Karski J., T. Karski \& M. Frelek-Karska and colleagues [1] [3]-[13]. The causes of the "Syndrome of Contractures and 


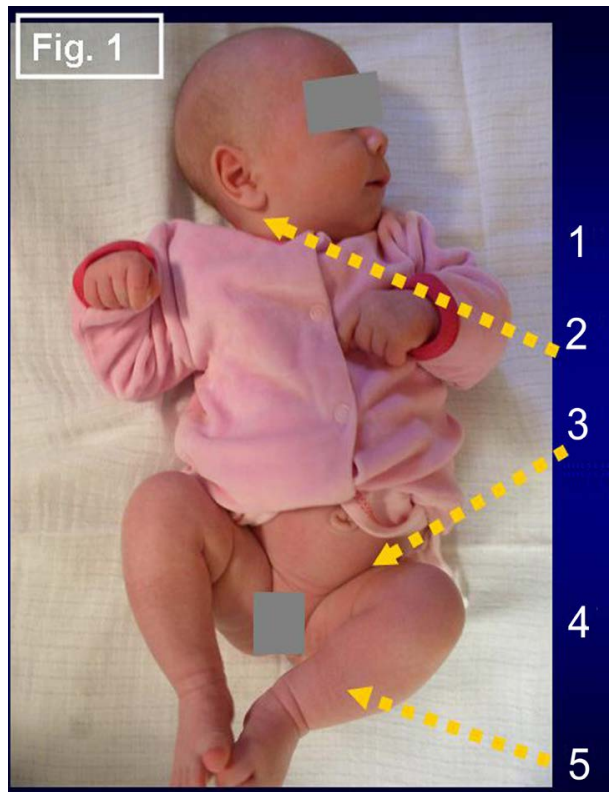

Figure 1. Three month old child; "Syndrome of Contractures and Deformities". 1. Plagiocephalia. 2. Right sided wry neck. 3. Limited abduction of the left hip as a symptom of dysplasia in form of DDH. 4. Infantile scoliosis left convex. 5. Moderate varus of shanks.

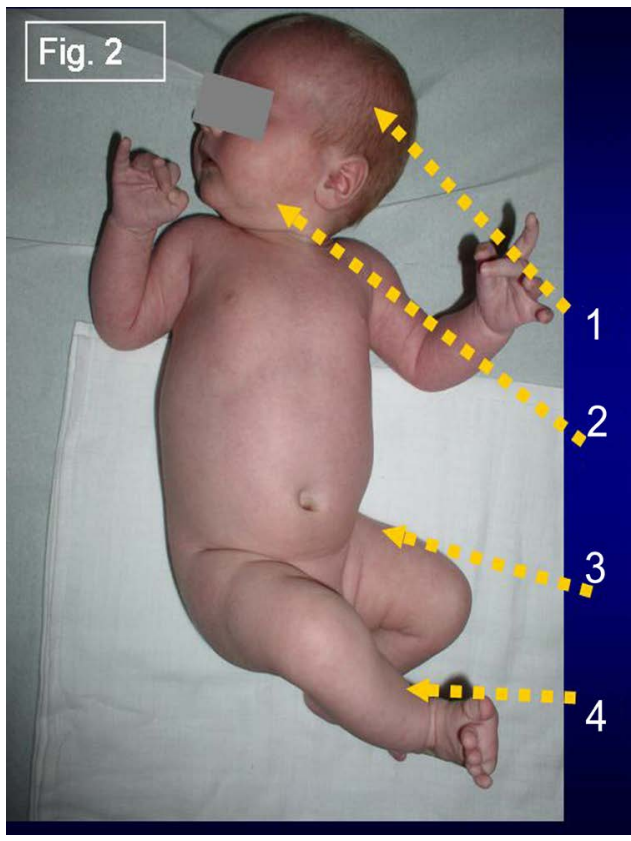

Figure 2. Two month old child, "Syndrome of Contractures and Deformities". 1. Plagiocephalia. 2. Torticollis sinister. Head turned to the right. 3. Restricted abduction of left hip. 4. Varus of shank.

Deformities" are: higher weight, greater length of the fetus's body and from the mother side: small abdomen during pregnancy, lack of amniotic fluids (oligohydramnios) and inconvenient, "androidal" or "platypelloid" pelvic bone anatomy. Asymmetrical contractures of joints imply discrepancies in ranges of movements of separate joints (hip: left: right, knee: left: right, left: right sides of spine). 


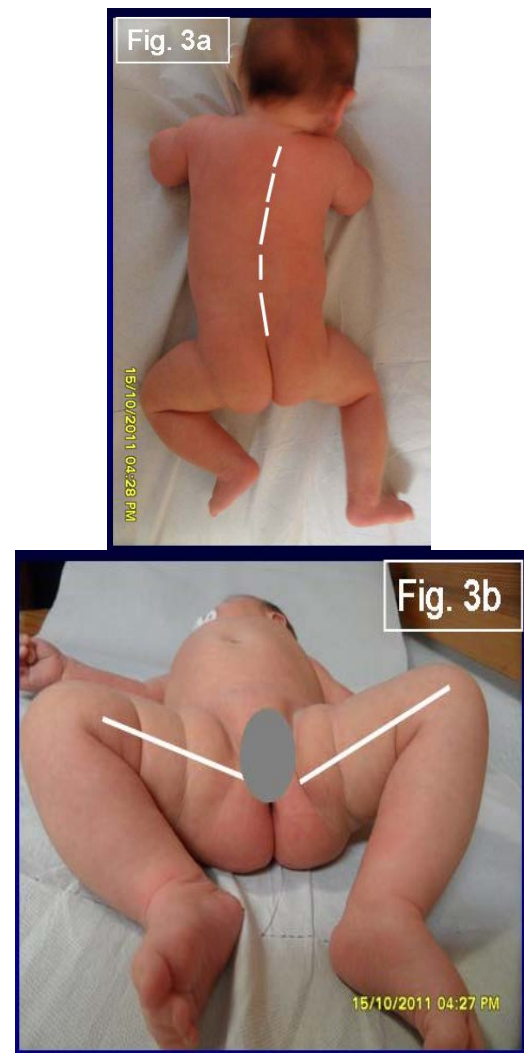

Figure 3. Typical "Syndrome of Contractures and Deformities". Child 1 month old. Changed axis of spine (scoliosis infantilis). Limited abduction of the left hip as symptom of dysplasia (DDH).

They can be additionally influenced by Minimal Brain Dysfunctions (MBD). MBD-means sub-spasticity of various groups of muscles-mostly flexors of hip, flexors of knees, and flexors of feet.

The "left sided SofCD" is more common, as a result of the first position of the fetus during pregnancy, when the fetus is placed on his back on the left side of the mother's uterus. Such pregnancies occur in $85 \%$ - 95\% of all cases [14] [15]. From the orthopaedic point of view, children with "Syndrome of Contractures and Deformities" has the dispositions to: infantile scoliosis, torticollis (wry neck), and dysplasia of the hip in form of development dysplasia of hip (DDH) according Klisic, mostly of the left hip because of the limited abduction of this joint (Figure 3(b)). In SofCD limited adduction of the right hip in their "extension position", in some cases even abduction contracture of this joint, play role in the development of the so-called idiopathic scoliosis, through "gait" and "permanent standing "at ease" on the right leg" (Figures 9-12).

Clinical symptoms of the "Syndrome of Contractures" are according Prof. Hans Mau [5] [7]-[13] [16] [17] [18]. There are asymmetrical position of various parts of the child's body and asymmetrical range of movements of joints (Figures 1-3):

1) Scull deformity (plagiocephaly);

2) Wry neck (torticollis muscularis); 
3) Infantile scoliosis (scoliosis infantilis) —other than idiopathic scoliosis;

4) Limited abduction of the left hip. Untreated, can lead to development of dysplasia. According to Prof. P. Klisic there is DDH (Developmental Dysplasia of the Hip [DDH]), which was mentioned earlier;

5) Contracture (shortening) of abductor muscles and soft tissues of the right hip (according to T. Karski), described as Haltungsschwäche ("weak posture") by $\mathrm{H}$. Mau-is the cause of oblique position of pelvis and through function- "standing" and "gait" is the cause of scoliosis;

6) Pelvic bone asymmetry, described by Prof. Mau-according ours observations is caused by shortening (contracture) of adductors of the left hip and by shortening (contracture) of abductors of the right hip (explanation of T, Karski);

7) Foot deformities-such as: pes equino-varus, pes equino-valgus, pes calcaneo-valgus.

In Lublin, in 2006 (T. Karski) we added to the "Syndrome of Contractures" in newborns and babies, as the eighth deformity, the excessive shank deformity (crura vara) which later can lead, under special conditions, to Blount disease [see literature-article published in German and in USA-Karski T. and co-authors, and T. Karski \& J. Karski]. Since 2006 we talk about the "Syndrome of Contractures and Deformities" (SofCD) what we described in chapter earlier.

\section{Material}

During 8 years (2009-2017) authors examined 922 newborns and babies with symptoms of the SofCD. The diagnosis criteria were similarly like using by Prof. Hans $\mathrm{Mau}$-the registration of clinical symptoms of asymmetries in position and in movement of head, neck, pelvis, hips, knees, feet. The control group consisted of 263 children presented by parents for examination, with no sign of the SofCD, but with others problems. In 2018 the material gathers 1033 cases.

Syndrome of contractures and its influence are on locomotors system [1] [2] [3] [4] [7] [9] [11] [16]-[24]. In article we present the cases of SofCD and its influence on:

1) dysplasia of the hip;

2) wry neck (torticollis);

3) biomechanical etiology of the so-called idiopathic scoliosis;

4) Blount disease [19] [20] [21] [22].

Hips [1] [3] [4] [8] [10] [11] [13] [19] [20] [25] [26]: The dysplasia of the hips can be connected with 1) the Syndrome of Contractures and Deformities (SofCD), with 2) laxity of joints and with 3) disorders of the central nerve system witch influence the movement of hips. The dysplasia of the hips in babies with the SofCD shows a deficit of abduction of hips, mostly on the left hip (Figure $3(b))$. The physiological treatment in this group of deformation is simple, easy and gives good results in relative short time. In therapy, as always, it is important to carry the child in full abduction and flexion of hips for over one year, as well to use orthopedic abduction devices (Figures 4-6). Unfortunately, in opposition to our recommendations, "wrongly educated" physiotherapists and rehabilitation 


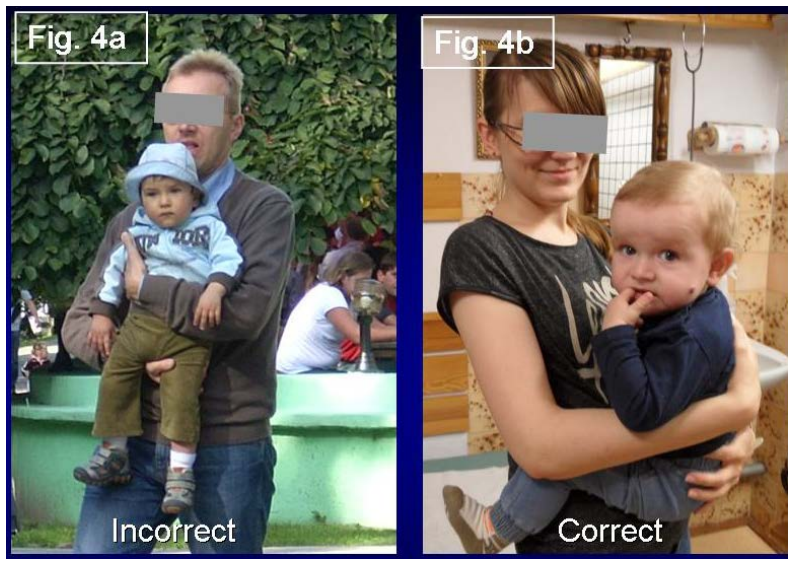

Figure 4. Improper way of carrying the child recommended by poorly educated orthopedic surgeons, physiotherapist, pediatricians (a). Proper way of carrying the child. Full abduction of the hips-the best prophylaxis for dysplasia (b).

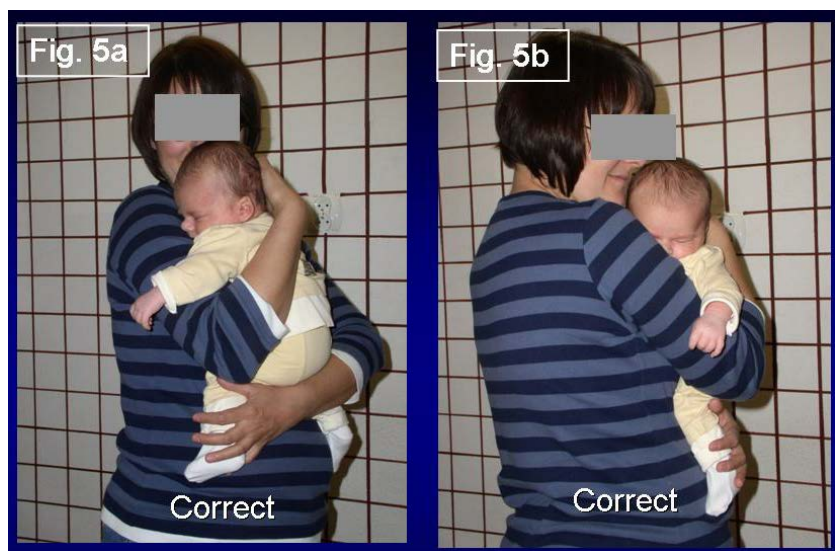

Figure 5. Two month old child with typical Syndrome of Contractures and Deformities. Carrying the child in full abduction of the hips is the prophylaxis for dysplasia. Twisting child's head to the left side is the best therapy of left sided wry neck (b).

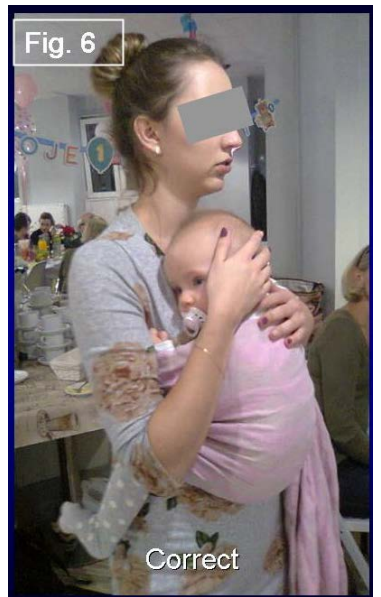

Figure 6. One year old child. Syndrome of Contracture and Deformities. Proper way of carrying the child in full abduction of the hips-the best method of therapy for dysplasia. Permanent rotation position of the head to the left side is the best method of therapy for the left sided wry neck. 
doctors-in Poland as well as also in abroad-recommend carrying children in a way they are facing to the front, to streets, to shops (Figure 4(a)).

In some patients we use orthopedic abduction devices. For successful treatment and for full "restitutio ad integrum" we need months or sometimes years. Children with dysplasia and laxity of joints need an especially long therapy. We let the child stand and walk at the age of one year, if in this moment the hips are healthy in a clinical and radiological examination. It is forbidden to stand and walk earlier and if it happens it is a mistake of therapy-by also such recommendation is giving by some pediatricians doctors. If the dysplasia of the hips has not been cured sufficiently during the first year of child's life, for prolonged therapy, we use a spongy triangle for walking or Weickert treasures-model for walking (Figure 7(a), Figure 7(b)).

Neck [2] [4] [5] [7] [13] [19] [20] [21] [23] [27] [28]: Very frequently (6\% to $8 \%$ of the Polish population) in newborns and babies occurs a wry neck-in Latin-torticollis muscularis or torticollis myogenes. There are three forms of such a deformity:

1) Torticollis connected with SofCD;

2) Torticollis after traumatic delivery;

3) Congenital wry neck with tumor neonatorum.

Until now in Poland, wry neck is treated in many Medical Centres with old methods of physiotherapy by stimulations, frequent, repeated movements, by Vojta method. This kind of therapy never gives sufficient results. Only permanent "rotation stretching position" in the direction of the torticollis side give a good result (Figure 5(b), Figure 6, Figure 8). This method of therapy was introduced in Lublin in July 1974 (44 years ago-T. Karski) and give success in all cases in age from 1 to 3 year-old patients. Here I would like to remind, that before 1974 in the Pediatric Orthopedic and Rehabilitation Department of Medical

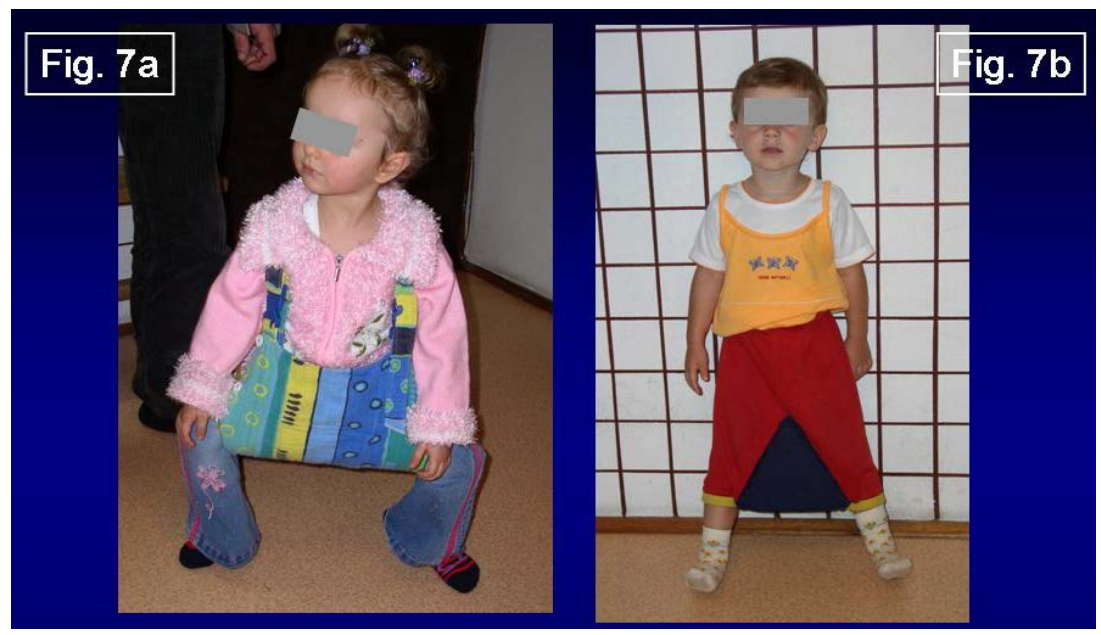

Figure 7. Two methods of treatment of hip dysplasia. (a) child with Weickert's trousers for walking. (b) child with spongy triangle. Walking in abduction is the best method for therapy of dysplasia in older children. The presented methods are better than orthopedic devices used when the child is laying down. 


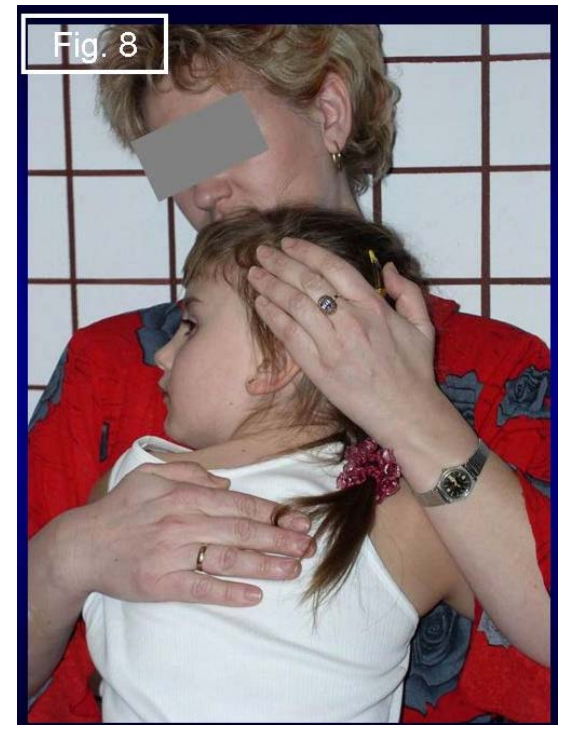

Figure 8. Three year old child. Stretching-rotation treatment to the left side for left sided wry neck is successful even for older children. At this age a successful therapy needs more time, even 2 - 3 years, if the time of the stretching lasts $1-2$ hours every day.

University in Lublin we had operated many patients, even 2 - 3 cases per week. From 1974 to 1995 the number operated patients was significantly smaller. In years 1995-2009 (in this time Prof. T. Karski was the head of the Department), we operated only 3 - 5 patients per year, commonly coming from the far regions of ours country.

Spine, scoliosis [7] [12] [13] [19] [21] [25] [29]-[36]: The biomechanical etiology of the so-called idiopathic scoliosis ("so-called"-because the etiology has been discovered and explained, 1995-T. Karski and J. Karski) is based on the asymmetry of movements of hips and on the asymmetry of functioning-"standing" and "gait". The history of Lublin discoveries are the following:

1995-First presentation of the biomechanical etiology during Orthopedic Congress in Szeged (Hungary);

1996-First publication in Germany;

1997-Confirmation that the "standing 'at ease' on the right leg" is an important cause in two groups of scoliosis;

2001-Description of the new classification-first and second group of scoliosis; 2004-Description of the third group of scoliosis;

2006-Ultimate description of the "model of the movement of the hips" and type of scoliosis (three groups and four types-see classification);

2007-Explanation why blind children do not have scoliosis (gait is without lifting of legs, standing is safe on both legs) and describing the "indirect, additional influences" in development of scoliosis, coming from Central Nerve System (CNS) in children with Minimal Brain Dysfunction (MBD). In children with MBD there are: 1) anterior tilt of pelvis, 2) extension contracture of the spine, 3) laxity of joints.

We present the following stages in the development of the so-called idiopathic 
scoliosis:

1) Asymmetry of position and range of movements of the hips resulting from the "Syndrome of Contracture and Deformities" (SofCD);

2) Limited movements of right hip: restricted adduction in strait position of joint, restricted internal rotation, frequent limited extension of both hip joints;

3) Next influences are connected with the function- "gait" and "standing". Here we explain: during walking, restricted movement-not presented in the right hip is transmitted to the pelvis and to the spine as compensatory movement, which causes rotation distortion of inter-vertebral joints and stiffness of the spine;

4) The next cause is connected with permanent standing "at ease" on the right leg. As a result, appear the left convex lumbar curve in scoliosis II-nd epg and in I-st epg type.

In the new classification of the so-called idiopathic scoliosis there are three groups and four types of spine deformities (Figures 9-12). Distinguishing types of scoliosis is important for the therapy. Here we explain: in every type of scoliosis, stretching exercises for spine, for hips and for proper position of pelvis are the only correct therapies. They should lead to a full and symmetrical movement of spine-flexion, deviation, rotation, the same in hips-full and symmetrical adduction, internal rotation and extension. In our program of therapy we never recommend strengthening exercises, but we recommend such sport arts as karate, taekwondo, aikido, yoga.

Shank, Blount disease [13] [19] [20] [21] [22]: The varus deformity of shank was added to the "Syndrome of Contractures" in 2006 [T. Karski] (Figures 13-15). In many newborns, as a result of adapting to mother's uterus, develop varus deformity of shanks. In some cases, varus deformity is bigger than "normal",

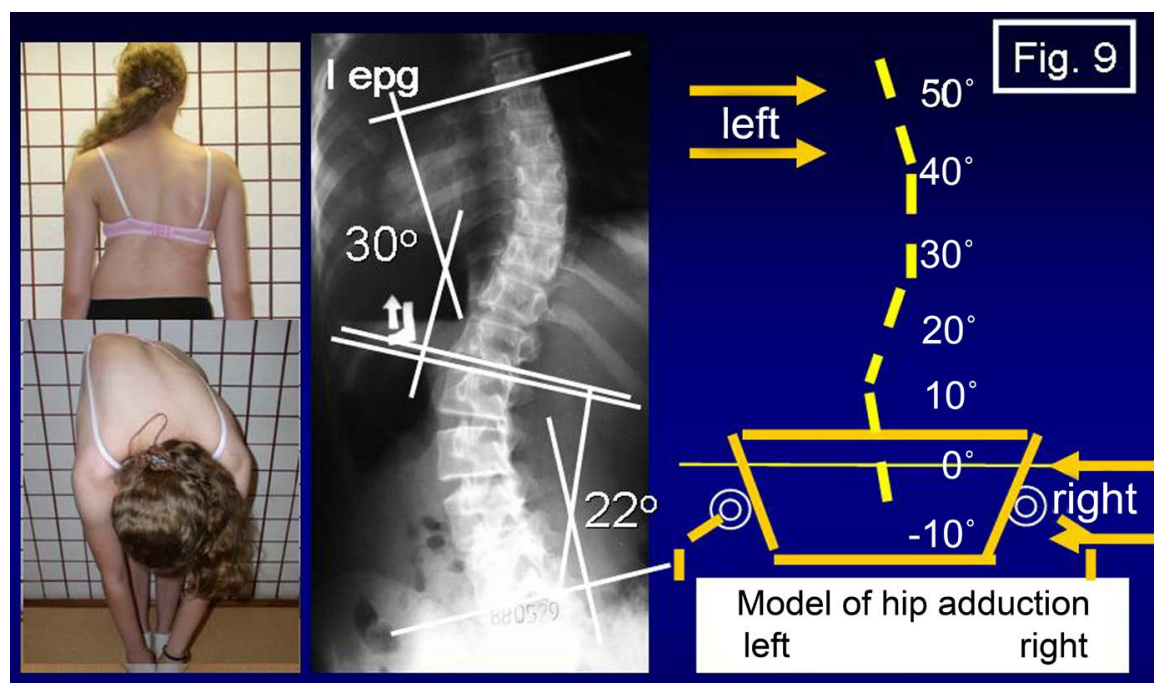

Figure 9. New classification. 15 year old patient. "S" scoliosis in I epg, 3D. Primary double curves. Connection with gait \& standing "at ease" on the right leg. Specific model of hips movements. In development-first rotation deformity, next curves. Stiffness of spine. Progression. 


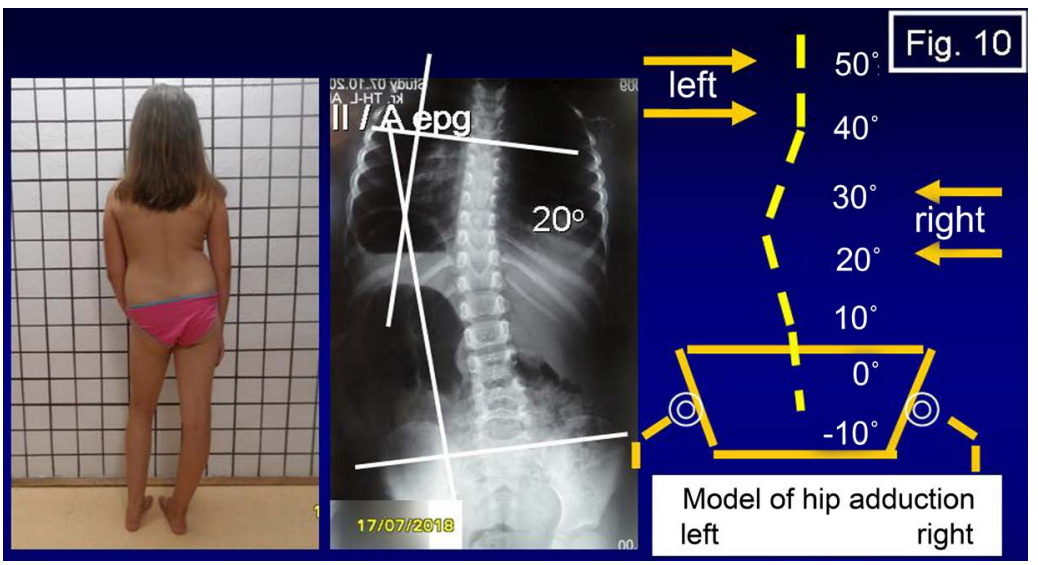

Figure 10. New classification. 10 year old patient. "C" scoliosis in II/A epg. 1D. Connection with standing "at ease" on the right leg. Specific model of hips movements. Flexible spine. No progression.

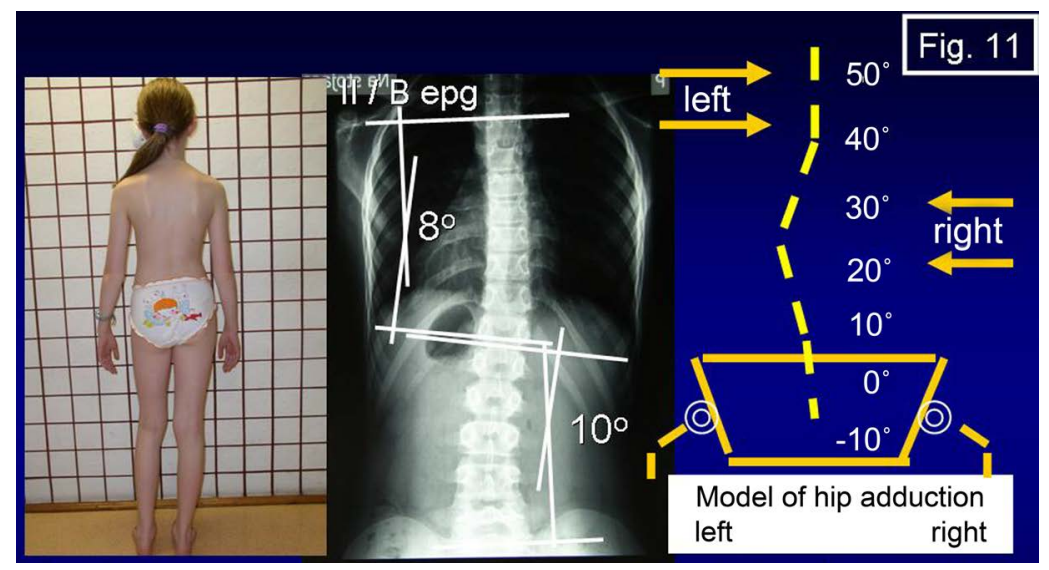

Figure 11. New classification. 13 year old patient. "S" scoliosis in II/B epg. 2D or mix. Thoracic curve secondary. Connection with standing "at ease" on the right leg plus laxity of joints or wrong exercises in previous therapy. Flexible spine. No progression or a small one.

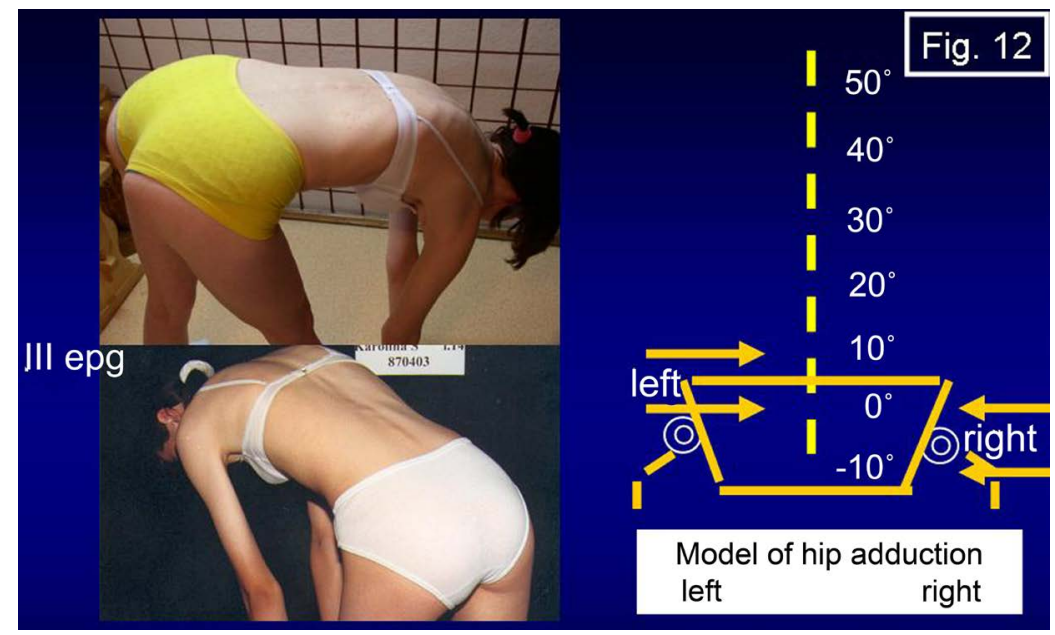

Figure 12. New classification. Two patients aged 18 and 20. Scoliosis "Ist" in IIIrd epg. Specific model of hips movements. Connection with gait only. 2D or mix. Stiffness of spine. No curves or a small one. 


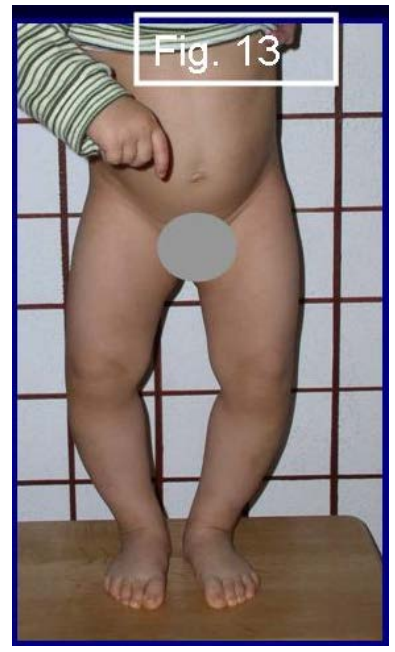

Figure 13. Varus deformity of shanks—-typical Blount disease.

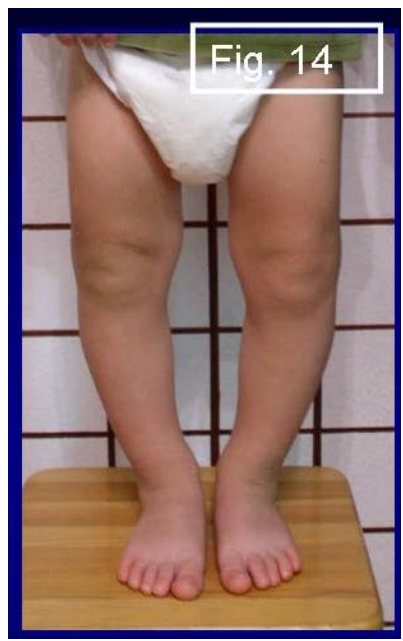

Figure 14. Varus deformity of shanks-Blount disease plus rickets.

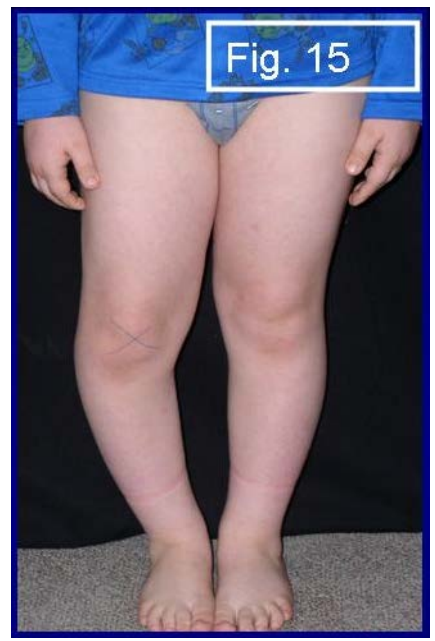

Figure 15. Varus deformity of shanks-one-sided Blount disease. Left leg self corrected. Treatment of children aged 1 - 3 years only by physiotherapy (look text). Older children-surgery. 
and then, it can trigger, under special conditions to Blount disease. These conditions are following:

1) premature, too early standing and walking, under the age of 1 ;

2) vitamin $D$ deficiency.

In such situations Blount disease can develop, it means varus in proximal part of shanks, in place of epiphysis and methaphysis. Primary Blount disease in every case is bilateral. In later years, one of the shanks, usually the left one, can correct itself spontaneously. The deformation of the right shank is durable and becomes bigger with time. Thus, one-sided deformity can be noticed in cases with the "Syndrome of Standing 'at ease' on the Right Leg" (new syndrome-see Literature).

All cases of Blount disease until 1981 in our Department had been operated. In the 80 ' we found the conservative method of therapy. We "use" for this therapy, the Heuter-Volkmann law. According to this law, pathological changes of axes of lower extremities develop when "existing loading bigger than normal and primary varus of shanks is observed". If loading or overloading is not present spontaneously appears correction of axis. Since 1981 we recommended parents to carry children with varus deformity 10 or even 20 degrees for 2 - 3 months, in some cases 4 months, until the shanks regain their normal axes. In this period the child shouldn't stand nor walk. To all cases of Blount disease we add vitamin D. After introducing such a conservative treatment, from 1981 until now, in all cases, in children aged from 1 to 2.5 , the axes of legs come to normal. We emphasize that the age for such treatment is 1 to 2.5 , in some cases -3 years. Older children have to be operated on, like before.

\section{Discussion}

In etiology of deformities and illnesses of movement apparatus can play role the following causal influences: congenital, hormonal, coming from Central Nerve System-in children with MBD, but we must remember about very frequent influences going from the "Syndrome of Contractures and Deformities" (SofCD). The asymmetries in SofCD-in position of part of the body of newborn and babies, in range of movement of joints can influence the development and growth of the child body [8] [9] [13] [19] [20] [23] [24] [29] [30] [32] [34] [35]. They can changed function-"standing" and "gait". Non treated can even influenced the function of hips, knee, feet, spine in adult period of life. So regarding to proper treatment of newborns, babies and youth persons we should see as prophylaxis management for the older people.

\section{Conclusions}

1) Every orthopedic surgeon and pediatric doctor, as well every physiotherapist, should be familiarized with the knowledge about the "Syndrome of Contractures and Deformities" (SofCD) based on Prof. Hans Mau's (Germany) experience. 
2) Every newborn and baby with the SofCD should be treated very early by proper nursing and using of orthopedic devices, older children by stretching exercises in order to reach symmetry of joint movements of hips, knees, feet, and spine.

3) Only symmetry of movements and of function enables proper body growth. This rule is especially important in prophylaxis of hip dysplasia and of scoliosis.

4) Effective treatment of small children with residual changes of SofCD should be considered an effective prophylaxis of insufficiency of the movement apparatus and as an important procedure against arthrosis of hips, knees, spine in older patients.

5) The aim of physiotherapy is to achieve symmetry of position, symmetry of movements of joints as well symmetry in development and growth.

6) For the treatment of older children we should use the stretching exercises to heal contracted (shortened) side or part of the body, and of region of joints but we never recommend strengthening exercises.

7) In therapy and prophylaxis of the so-called idiopathic scoliosis we recommend the stretching exercises for right hips to obtain full movement, flexion-rotation exercises for spine, embryo position for rest and sleeping in the nights, and standing "et ease" only on the left leg, sport, especially exercises like karate, taekwondo, aikido, kung fu.

8) Additionally, in treatment we can use thermotherapy, magnetic fields, biodynamic (diadynamic), laser, and massages. Exercises in geothermal water are especially useful.

\section{Acknowledgements}

1) Many thanks to Honorata Menet for correction of English text.

2) All patients-adults and children-are agree to reproduce the figures in the scientific publication, in Surgical Science Journal, in USA.

\section{Conflicts of Interest}

The authors declare no conflicts of interest regarding the publication of this paper.

\section{References}

[1] Dega, W. (1932) Badania z dziedziny etiologii wrodzonego zwichnięcia biodra [Research on the Subject of the Congenital Dysplasia of the Hip]. Chirurgia Narzadu Ruchu, 144-151.

[2] Golden, K.A., Beals, S.P., Littlefield, T.R., et al. (1999) Sternocleidomastoid Imbalance versus Congenital Muscular Torticollis: Their Relationship to Positional Plagiocephaly. The Cleft Palate-Craniofacial Journal, 36, 256-261. https://doi.org/10.1597/1545-1569_1999_036_0256_sivcmt_2.3.co_2

[3] Hensinger, R.N. (1979) Congenital Dislocation of the Hip. Clinical Symposium, 31-35.

[4] Howorth, B. (1977) The Etiology of Congenital Dislocation of the Hip. Clinical Or- 
thopedics, 29, 164-179.

[5] Cheng, J.C., Tang, S.P., Chen, T.M., et al. (2000) The Clinical Presentation and Outcome of Treatment of Congenital Muscular Torticollis in Infants: A Study of 1,086 Cases. Journal of Pediatric Surgery, 35, 1091-1096.

https://doi.org/10.1053/jpsu.2000.7833

[6] Watson, G.H. (1971) Relation between Side of Plagiocephaly, Dislocation of Hip, Scoliosis, Bat Ears, and Sternomastoid Tumour. Archives of Disease in Childhood, 46, 203-210. https://doi.org/10.1136/adc.46.246.203

[7] Karski, T. (1996) Kontrakturen und Wachstumsstörungen im Hüft- und Beckenbereich in der Ätiologie der sogenannten "Idiopathischen Skoliosen"-Biomechanische Überlegungen [The Contracture and Growth Abnormalities in Hip and Pelvis Region in the Etiology of So-Called Idiopathic Scoliosis-Biomechanical Considerations]. Orthopädische Praxis, 32, 155-160.

[8] Karski, T., Kałakucki, J. and Karski, J. (2006) Syndrome of Contractures (According to Mau) with the Abduction Contracture of the Right Hip as Causative Factor for Development of the So-Called Idiopathic Scoliosis. Studies in Health Technology and Informatics, 123, 34-39.

[9] Malawski, S. (1994) Własne zasady leczenia skolioz niskostopniowych w świetle współczesnych poglądów na etiologię i patogenezę powstawania skolioz [Own Principles of the Therapy of Beginnings Scoliosis in Actually Point of View to Etiology and Pathogenesis of Scoliosis]. Chirurgia Narządów Ruchu i Ortopedia Polska, 59, 3, 189-197.

[10] Barlow, T.G. (1962) Early Diagnosis and Treatment of Congenital Dislocation of the Hip. Journal of Bone and Joint Surgery, 44-B, 292-3012.

[11] Green, N.E. and Griffin, P.P. (1982) Hip Dysplasia Associated with Abduction Contracture of the Contra Lateral Hip. The Journal of Bone and Joint Surgery, 64, $1273-1281$.

[12] Tomasz, K., Kałakucki, J. and Karski, J. (2007) Relationship of "Syndrome of Contractures" in Newborns with the Development of the So-Called Idiopathic Scoliosis. World Journal of Pediatrics, 3, 254-259.

[13] http://www.ortopedia.karski.lublin.pl/

[14] Oleszczuk, J., Szymański, W. and Wilczyński, B. (1999) Patologia Ciąży (Pathological Pregnancy). In: Rudolf, K., Ed., Położnictwo, Dream Publ., Kraków, 395-499.

[15] Oleszczuk, J., Chazan, B., Kamiński, K., Leszczyńska-Gorzelak, B., Skręt, A. and Szymański, W. (1999) Poród Patologiczny (Pathological Childbirth/Delivery). In: Rudolf, K., Ed., Położnictwo, Dream Publ., Kraków, 291-337.

[16] Mau, H. (1983) Powstawanie skoliozy u małych dzieci w: Wczesne wykrywanie i zapobieganie progresji bocznych skrzywień kręgosłupa (Early Screening and Prophylaxis of Scoliosis) Materiały z Sesji Naukowej PAN. PZWL, Warszawa, 34-42.

[17] Mau, H. (1979) Zur Ätiopathogenese von Skoliose, Hüftdysplasie und Schiefhals im Säuglinsalter (Ethiopathogenesis of Scoliosis, Hip Dysplasia and Torticollis in Infants). Zeitschrift Fr Orthop dische Chirurgie, 5, 601-605.

[18] Mau, H. (1982) Die Atiopatogenese der Skoliose (Ethiopathogenesis of Scoliosis). Bücherei des Orthopäden, Band 33, Enke Verlag Stuttgart, 1-110.

[19] Jacek, K. and Karski, T. (2012) Zespół przykurczów u noworodków i niemowląt przyczyną odległych dysfunkcji narządu ruchu w tym skolioz tzw. idiopatycznych. Wykrywanie zagrożeń oraz zasady profilaktyki przez zabiegi fizjoterapeutyczne [Syndrome of Contractures in Newborns and Babies as a Cause of Deformities in 
Movement Apparatus and in Etiology of the So-Called Idiopathic Scoliosis in Next Years of Life. New Screening and Treatment by Physiotherapy]. Zesz. Nauk., WSSP T. 15, S. 11-25, Bibliogr. Poz. 43.

[20] Karski, T. and Jacek, K. (2015) "Syndrome of Contractures and Deformities" according to Prof. Hans Mau as Primary Cause of Hip, Neck, Shank and Spine Deformities in Babies, Youth and Adults. American Research Journal of Medicine and Surgery, 1, 1-10.

[21] Tibor, V. and Karski, T. (2000) Skoliozy tzw. idiopatyczne-przyczyny, rozwój i utrwalanie się wady. Profilaktyka i zasady nowej rehabilitacji [The Etiology of the So-Called Idiopathic Scoliosis. Progress and Fixation of the Spine Disorders. The Prophylaxis and Principles of the New Rehabilitation Treatment]. KGM, Lublin, 1-143.

[22] Karski, T., Drabik, Z., Karski, J. and Agbemey, E. (1994) Osteotomien in der Behandlung von Kindern mit Crura vara (M. Blount) [Surgery in the Treatment of Children with Crura Vara (Blount Disease) Orthop]. Praxis, Heft 9, 582-585.

[23] Karski, T., Frelek-Kars, M., Karski, J., Madej, J. and Kałakucki, J. (2001) Zespół przykurczów u noworodków i niemowląt przyczyną odległych dysfunkcji narządu ruchu w tym tzw. skolioz idiopatycznych. Wykrywanie zagrożeń nieprawidłowego rozwoju kręgosłupa i zasady nowej profilaktyki skolioz [The Syndrome of Contractures at Newborns and Babies as a Cause of Dysfunctions of Skeletal System and among Others of the So-Called Idiopathic Scoliosis. The Discovery of the Danger of the Oncoming Scoliosis. Rules of New Prophylactics]. Międzynarodowa Konferencja Naukowa: Uwarunkowania rozwoju sprawności i zdrowia. Częstochowa, 10-11 grudnia. Progr. i streszcz, s. 11-12.

[24] Karski, T., Karski, J., Madej, J. and Latalski, M. (2002) Persönliche Überlegungen zur Ätiologie der idiopathischen Skoliosen. Praktische Hinweisen zur Entdeckung beginnender Skoliosen. Möglichkeiten der Prophylaxe [Considerations about Etiology of the Idiopathic Scoliosis. Practical Directions in Discovering of the Beginnings Stages of Scoliosis]. Orthopädische Praxis 02/, 38 Jahrgang, Seite 75-83.

[25] Kane, A.A., Mitchell, L.E., Craven, K.P., et al. (1996) Observations on a Recent Increase in Plagiocephaly without Synostosis. Pediatrics, 97, 877-885.

[26] Rogers, G.F. and Mulliken, J.B. (2003) The Significance of Torticollis in Deformational Posterior Plagiocephaly [Abstract]. Proceedings of the Tenth International Congress of the International Society of Craniofacial Surgery, 21-24 September 2003, 61 .

[27] Karski, T. (2002) Etiology of the So-Called "Idiopathic Scoliosis". Biomechanical Explanation of Spine Deformity. Two Groups of Development of Scoliosis. New Rehabilitation Treatment. Possibility of Prophylactics, Studies in Technology and Informatics. In: Theodoros, B., Ed., Research into Spinal Deformities 4, IOS Press, Washington, Vol. 91, 37-46.

[28] Karski, T., Karski, J. and Kałakucki, J. (2003) Minimal Incongruence of the Hip Joint at Youth and Adults Treated and Not-Treated because of DDH in Baby Period. 2nd Annual International Conference SICOTISIROT, Cairo, 10-13 September 2003, SFS8-H.

[29] Karski, T. (2011) Biomechanical Etiology of the So-Called Idiopathic Scoliosis (1995-2007) - Connection with "Syndrome of Contractures"-Fundamental Information for Pediatricians in Program of Early Prophylactics. Journal of US-China Medical Science, 8, 72-86.

[30] Jacek, K. and Karski, T. (2013) So-Called Idiopathic Scoliosis: Diagnostic Tests; Examples of Children Incorrect Treated: New Therapy by Stretching Exercises and 
Results. Journal of Novel Physiotherapies, 3, 147.

[31] Karski, T. and Karski, J. (2015) Biomechanical Etiology of the So-Called Idiopathic Scoliosis (1995-2007). Causative Role of "Gait" and "Permanent Standing "at Ease" on the Right Leg. New Classification. Principles of New Therapy and Causal Prophylaxis. Canadian Open Medical Science \& Medicine Journal, 1, 1-16.

[32] Karski, J., Karski, T., Kandzierski, G., Tarczy, M., Kałakucki, J. and Latalski, M. (2005) "Zespół przykurczów" u noworodków i niemowląt wg prof. Hansa Mau w wyjaśnieniu "geografii” i niektórych klinicznych cech skolioz tzw. idiopatycznych. ["Contracture syndrome" in Newborns and Infants according to Prof. Hans Mau as an Explanation of the "Geography" and Certain Clinical Features of Idiopathic Scoliosis]. Ortopedia, Traumatologia, Rehabilitacja, 23-27.

[33] Karski, T. (2005) Biomechanical Explanation of Etiology of the So-Called Idiopathic Scoliosis. Two Etiopahtological Groups-Important for Treatment and Neo-Prophylaxis. Pan Arab Journal, 9, 123-135.

[34] Jacek, K., Kalakucki, J., Karski, T. and Dlugosz, M. (2006) “Syndrom kontraktur” (podle $\mathrm{Mau}$ ) s abdukční kontrakturou pravého kyčelního kloubu jako příčinného faktoru vývoje tzv. idiopatické skoliózy [Syndrome of Contractures" (According to Mau) with the Abduction Contracture of the Right Hip as Causative Factor for Development of the So-Called Idiopathic Scoliosis]. Pohybove Ustroji (Locomotor System)/Czech Republic, 81-88.

[35] Karski, T., Kałakucki, J. and Karski, J. (2006) "Syndrome of Contractures" (According to Mau) with the Abduction Contracture of the Right Hip as Causative Factor for Development of the So-Called Idiopathic Scoliosis. Technology and Informatics, Vol. 1, 2, 3, In: Uyttendaele, D. and Dangerfield, P.H., Eds., Research into Spinal Deformities 5, IOS Press, Washington, 34-39.

[36] Jacek, K., Karski, T. and Kędzierski, Z. (2013) Syndrome of Contractures and Deformities" in Newborns and Infants according Mau-And Its Influence for Secondary Deformities of Movement Apparatus in Babies, Youth and Adults. Pohybove Ustroji (Locomotor System), 315-317. 